\title{
全方向移動ロボットのための差動駆動操舵機構の開発
}

\author{
北川 秀 夫*1 大 野 貴*2 三 好 孝 典*2 寺 嶋 一 彦*2
}

\section{Development of Differential-Drive Steering System for Omnidirectional Mobile Robot}

\author{
Hideo Kitagawa*1, Takashi Ohno*2, Takanori Miyoshi*2 and Kazuhiko Terashima*2
}

\begin{abstract}
Holonomic omnidirectional mobile robot is useful with its high mobility in narrow or crowded place, and omnidirectional robot equipped with normal tires is desired for difference excess, vibration suppression and riding comfort. Caster-drive mechanism using normal tire has been developed to realize a holonomic omnidiredctional robot, however, there remains some problems. This paper presents effective systems to control the caster-drive wheels of omnidirectional mobile robot. Two kinds of Differential-Drive Steering System (DDSS) are proposed to improve the operation ratio of motors. One is using bevel pair gear and the other is using planetary gear to generate driving and steering torque effectively from two motors. Simulation results show the proposed system is effective for holonomic omnidirectional mobile robots.
\end{abstract}

Key Words: Omnidirectional Mobile Robot, Holonomic, Caster-Drive, Planetary Gear

\section{1. 緒言}

全方向移動機構は，切り返しや大回りをすることなく任意の 方向への並進，回転動作が可能であるため，工場内で使用され ている自動搬送車や狭所での高い機動性を持つ車い寸等への応 用が可能であり，その有用性が注目されている。

二次元平面を任意の方向へ瞬時に移動可能な車両はホロノミッ ク全方向移動車両と呼ばれ，これまでにいくつかの機構が考案 され，その適用例も報告されている [1]〜 [6]. しかし，これらの 機構はメカナムホイール, ボールホイール, オムニディスク, オ ムニホイールといった特殊車輪を用いて全方向移動機能を実現 しているため, 通常のゴムタイヤを用いた車両に比べて, 段差 乗り越え等を含む走破性や走行安定性（振動, 車輪のスリップ 等）に大きな問題がある。

通常のタイヤを装着できる機構では, 移動前に進行方向に夕 イヤの向きを変える動作が必要となるノンホロノミック全方向 移動機構 [7] [8] も提案されているが, ホロノミック全方向移動 機構としては, 和田らにより双輪キャス夕型駆動機構を用いた全 方向移動ロボット [9] や, 車輪数, 配置の自由度の高いオフセッ ト型駆動輪（アクティブキャスタ）を用いた全方向移動ロボッ 卜 [10]〜 [12] が開発されている. オフセット型駆動輪は, 操舵軸 から車輪の転がり方向に一定距離離れた位置に駆動車輪を有す

原稿受付 2008 年 6 月 16 日

${ }^{* 1}$ 岐皁工業高等専門学校

$* 2$ 豊橋技術科学大学

${ }^{* 1}$ Gifu National College of Technology

${ }^{* 2}$ Toyohashi University of Technology

ロ 本論文は学術性で評価されました。
るキャス夕構造をとっていて, 操舵軸と駆動輪を独立にモー夕 で制御することにより，平面内での任意の方向への運動を実現 している。しかし，操舵軸と駆動輪を個別のモータで制御する 必要があるため, モー夕の運用率の面で以下の問題がある。な お，モー夕の運用率は搭載されている各モー夕の定格出力の総 和に対する各モー夕の動作時の平均出力で定義しており, この 值が大きいほどモー夕を有効に使用している，すなわち同じ動 作を実現するのに小出力のモータでよく，小型化が可能になる と考えられる.

前進に代表される一定の動作を続けている間は，駆動用モー 夕のみが動作して操舵用モータがアイドル状態になる。一方, 方 向転換等の動作を行う際には, 瞬間的に操舵用モー夕に対して 高負荷がかかる．すなわち，たまにしか動かさないからといっ て操舵用モー夕の出力を低くするわけにはいかず，駆動用モー 夕と操舵用モー夕の双方に高出力のものが必要になる。 その結 果, モー夕の運用率が悪くなり, モー夕の総出力（総質量）が 必要以上に大きくなってしまう。

本研究では, この問題を解決するため, 特殊なギア機構を用 いて二つのモータの出力を干渉させることにより, モータの運 用率を向上させるオフセット型駆動輪を開発し, 比較的低出力 のモータで構成可能な全方向移動ロボットを実現することを目 的とする，なお，双輪キャス夕機構においても構造的に同様の 効果が期待できるが, 双輪キャス夕機構においては別途受動輪 が必要になる点と駆動輪が二輪に限定されてしまう点が問題と なる．提案する方式では，オフセット駆動輪の利点をそのまま 生かしつつ, 双輪キャス夕機構のように駆動時にも操舵時にも すべてのモー夕を有効に利用することが可能となる． 


\section{2. 動 作 原 理}

本章では，まずオフセット型駆動輪による全方向移動の原理 を説明した後，それを有効に実現するために本論文で提案する 2 種類の差動駆動操舵機構の動作原理について述べる.

\section{1 オフセット型駆動輪を用いた全方向移動機構}

Fig. 1 にオフセット型駆動輪を示す. 地面に固定された座標 系 $O-X Y$ に対して $O_{w}-X_{w} Y_{w}$ はキャス夕に固定された座 標系で, 操舵軸を原点 $O_{w}$ とし, 車輪の進行方向と $X_{w}$ 軸が 一致するように設定する。これにより，車輪の状態は $O-X Y$ 座標系における $O_{w}$ の位置 $\left(x_{w}, y_{w}\right)$ と, $X$ 軸に対する $X_{w}$ 軸 の角度 $\theta_{s}$ により表すことができる。

半径 $r$ の駆動輪を回転速度 $\omega_{w}$ で回転させることにより $X_{w}$ 軸方向の移動速度 $\dot{x}_{w}=r \omega_{w}$ が発生し, 操舵軸を回転速度 $\omega_{s}$ で回転させることにより $Y_{w}$ 軸方向の移動速度 $\dot{y}_{w}=s \omega_{s}$ が 発生する。ここで $s$ は操舵軸と夕イヤ接地点との間に存在する $X_{w}$ 軸方向のオフセットである，操舵軸を回転速度 $\omega_{s}$ で回転さ せた際に, タイヤ接地点の摩擦で運動が拘束されるため, その 反作用として操舵軸に $Y_{w}$ 軸方向の速度 $\dot{y}_{w}$ が発生する。 $\omega_{w}$, $\omega_{s}$ を制御してこの $\dot{x}_{w}, \dot{y}_{w}$ の大きさを変化させることにより, 任意の方向，大きさの二次元並進速度べクトルが生成する.

Fig. 2 に，初期状態で前方を向いているオフセット型駆動輪 を右に向かって横移動させるときの動作を示す。車輪接地点の 軌跡は曲線を描いているものの， $\dot{x}_{w}, \dot{y}_{w}$ の值を適切に制御す れば，操舵軸すなわちそこに固定されているロボット本体を真 横に並進させることができる。

全方向移動機構の各車輪レベルでは， $\dot{x}_{w} ， \dot{y}_{w}$ が制御可能，も しくは従動できればよく，機構の向きは制御する必要がない。そ のため, 車輪の状態ベクトル $\boldsymbol{x}_{w}$, 入力ベクトル $\boldsymbol{u}_{w}$ はそれぞ れ $\boldsymbol{x}_{w}=\left[x_{w}, y_{w}\right]^{T}, \boldsymbol{u}_{w}=\left[\omega_{w}, \omega_{s}\right]^{T}$ と表すことができ, 順運 動学式は

$$
\dot{\boldsymbol{x}}_{w}=\boldsymbol{B}_{w} \boldsymbol{u}_{w}
$$

ただし
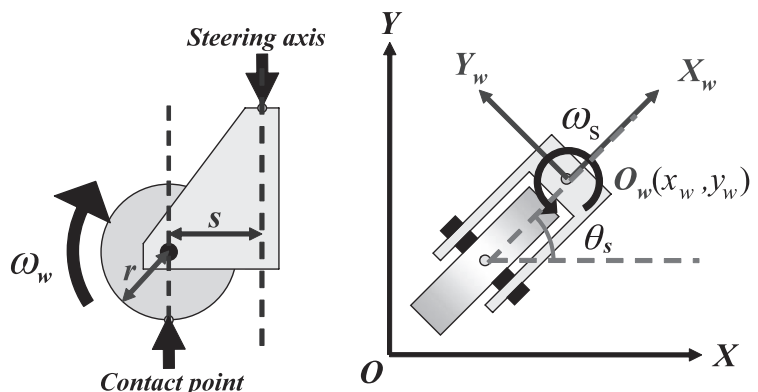

Fig. 1 Offset steered driving wheel

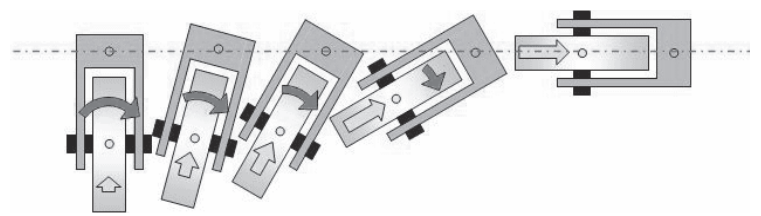

Fig. 2 Lateral motion to right

$$
\boldsymbol{B}_{w}=\left[\begin{array}{cc}
r \cos \theta_{s} & -s \sin \theta_{s} \\
r \sin \theta_{s} & s \cos \theta_{s}
\end{array}\right]
$$

となり，逆運動学式は

$$
\boldsymbol{u}_{w}=\boldsymbol{B}_{w}^{-1} \dot{\boldsymbol{x}}_{w}
$$

ただし，

$$
\boldsymbol{B}_{w}^{-1}=\left[\begin{array}{cc}
\frac{1}{r} \cos \theta_{s} & \frac{1}{r} \sin \theta_{s} \\
-\frac{1}{s} \sin \theta_{s} & \frac{1}{s} \cos \theta_{s}
\end{array}\right]
$$

となる。

二次元平面を任意の方向へ瞬時に移動可能なホロノミック全 方向移動ロボットの 3 自由度の動作を実現するには，このオフ セット駆動輪を 2 輪以上用いればよい。また，モー夕数を減ら したい場合は，このオフセット駆動輪を二つのモータで任意の 数だけ同期駆動させて，さらに回転機構を車両に追加すること により，三つのモータでの 3 自由度動作が実現できる。

\section{2 傘歯車型差動駆動操舵機構（DDSS Type D）}

本論文で提案する差動駆動操舵機構 (Differential-Drive Steering System：以降 DDSS）とは, 二つのモータと差動歯 車機構を用い，車輪の駆動と操舵を行う機構である。差動歯車 機構に二つのモータから入力を与え, 駆動, 操舵の二つの出力 を制御する。

DDSS には 众歯車型（Type D）と遊星歯車型（Type P）が ある．傘歯車型は自動車に用いられているディファレンシャル ギア機構と同じ構成になっていて，Fig. 3 に示されるように傘 歯車 $A, B, C$ およびキャリア $D$ からなり, 歯車 $A, B$ の歯 数 $Z_{A}, Z_{B}$ が等しい.

二つのモータからの入力は，自動車であればタイヤが取り付 けられる $A, B$ にそれぞれ入力され, 駆動出力は $C$ から, 操 舵出力は $D$ から出力される. 入力 $A, B$ に逆方向に同じ大き さの回転速度を入力すると， $D$ は回転せず $C$ のみ回転して，駆 動成分のみ出力される. Fig. 3 に示す $A, B, C, D$ それぞれ の回転速度を $\omega_{A}, \omega_{B}, \omega_{C}, \omega_{D}$ とし, $A, B, C$ それぞれの 歯数を $Z_{A}, Z_{B}, Z_{C}$ とすると, 駆動成分のみの場合は

$$
\begin{aligned}
& \omega_{A}=-\omega_{B}=\frac{Z_{C}}{Z_{A}} \omega_{C} \\
& \omega_{D}=0
\end{aligned}
$$

となる。一方，入力 $A, B$ に同方向に同じ大きさの回転速度を 入力すると, $C$ は回転せず $D$ のみ回転して, 操舵成分のみ出 力される.

$$
\omega_{A}=\omega_{B}=\omega_{D}
$$

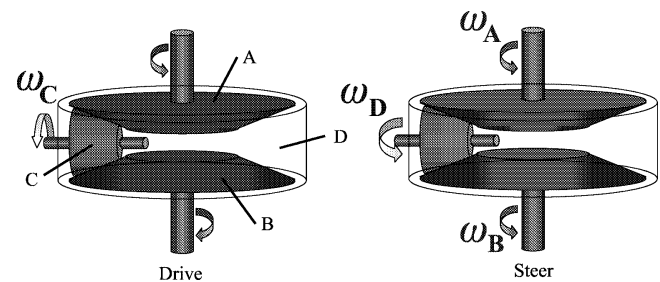

Fig. 3 DDSS Type D 


$$
\omega_{C}=0
$$

駆動および操舵成分が混在する運動に関しても, モータ入力 $\boldsymbol{u}_{P}=\left[\omega_{A}, \omega_{B}\right]^{T}$ により, 駆動・操舵出力 $\boldsymbol{u}_{w}=\left[\omega_{w}, \omega_{s}\right]^{T}$ を 独立に制御することが可能となる。その順運動学式は

$$
\boldsymbol{u}_{w}=\left[\begin{array}{c}
\omega_{C} \\
\omega_{D}
\end{array}\right]=\boldsymbol{B}_{D} \boldsymbol{u}_{P}
$$

ただし，

$$
\boldsymbol{B}_{D}=\left[\begin{array}{cc}
\frac{Z_{A}}{2 Z_{C}} & -\frac{Z_{A}}{2 Z_{C}} \\
\frac{1}{2} & \frac{1}{2}
\end{array}\right]
$$

となり，逆運動学式は

$$
\boldsymbol{u}_{P}=\boldsymbol{B}_{D}^{-1} \boldsymbol{u}_{w}
$$

ただし，

$$
\boldsymbol{B}_{D}^{-1}=\left[\begin{array}{cc}
\frac{Z_{C}}{Z_{A}} & 1 \\
-\frac{Z_{C}}{Z_{A}} & 1
\end{array}\right]
$$

となる。

\section{3 遊星歯車型差動駆動操舵機構 (DDSS Type P)}

次に, 同じ動作を実現するための別の機構を提案する. その基 本構造は Fig. 4 のように, 減速機として利用されている $2 \mathrm{~K}-\mathrm{H}$ 型遊星歯車機構と同等の構成となっている. 中心のサンギア $A$, 最外周のリングギア $B$, サンギアとリングギアに挟まれたプラ ネタリギア $C$ およびプラネタリギアを支えるプラネタリキャリ ア $D$ から構成されていて, $C$ は $A, B$ とかみ合っており, $C$ の軸は $D$ によって支持されている。一般的な遊星歯車減速機 として使用する場合にはどれか一つの回転体を固定して 1 入力 1 出力とするが, 提案する遊星歯車型 (Type P) の DDSS で は何れも固定しない 2 入力 2 出力システムとする.

Fig. 4 の遊星歯車機構を用いた DDSS の基本構造を Fig. 5 に示す． $E$ はプラネタリキャリア $D$ を保持する車体で, 二つ のモータは $E$ に固定される. 二つのモータからの入力はそれ ぞれ $A, B$ に入力され, 駆動出力は $C$ から, 操舵出力は $D$ か ら出力される. $C$ は傘歯車により回転方向を $90^{\circ}$ 変えられ, 車 輪を回転させる。

ここで, $\omega_{D}=0$ の場合は駆動のみ出力される. Fig. 4 のよj に $A, B, C, D$ それぞれの回転角速度を $\omega_{A}, \omega_{B}, \omega_{C}, \omega_{D}$
とし, $A, B, C$ それぞれの歯数を $Z_{A}, Z_{B}, Z_{C}$ とすると, 以 下の関係式が成り立つ.

$$
\begin{aligned}
& \omega_{A}=-\frac{Z_{B}}{Z_{A}} \omega_{B}=-\frac{Z_{C}}{Z_{A}} \omega_{C} \\
& \omega_{D}=0
\end{aligned}
$$

一方， $\omega_{C}-\omega_{D}=0$ となる場合は操舵のみ出力される.これ は, 操舵のみを出力する場合には, $C$ と $D$ が一体となって回 転して，駆動成分が 0 になるためである。この場合は

$$
\omega_{A}=\omega_{B}=\omega_{C}=\omega_{D}
$$

と，すべての角速度が等しくなる.

運動学式を以下に示す. モータ入力 $\boldsymbol{u}_{P}=\left[\omega_{A}, \omega_{B}\right]^{T}$ から駆 動 ·操舵出力 $\boldsymbol{u}_{w}=\left[\omega_{w}, \omega_{s}\right]^{T}$ を求める順運動学式は

$$
\boldsymbol{u}_{w}=\left[\begin{array}{c}
\omega_{C}-\omega_{D} \\
\omega_{D}
\end{array}\right]=\boldsymbol{B}_{P} \boldsymbol{u}_{P}
$$

ただし，

$$
\boldsymbol{B}_{P}=\left[\begin{array}{cc}
-\frac{Z_{A} Z_{B}}{Z_{C}\left(Z_{A}+Z_{B}\right)} & \frac{Z_{A} Z_{B}}{Z_{C}\left(Z_{A}+Z_{B}\right)} \\
\frac{Z_{A}}{Z_{A}+Z_{B}} & \frac{Z_{B}}{Z_{A}+Z_{B}}
\end{array}\right]
$$

となり, 逆運動学式は

$$
\boldsymbol{u}_{P}=\boldsymbol{B}_{P}^{-1} \boldsymbol{u}_{w}
$$

ただし，

$$
\boldsymbol{B}_{P}^{-1}=\left[\begin{array}{cc}
-\frac{Z_{C}}{Z_{A}} & 1 \\
\frac{Z_{C}}{Z_{B}} & 1
\end{array}\right]
$$

となる。

さらに, $A, B, C, D$ それぞれに加わるトルク $T_{A}, T_{B}, T_{C}$, $T_{D}$ の関係は

$$
\left[\begin{array}{c}
T_{C} \\
T_{D}
\end{array}\right]=\left[\begin{array}{cc}
-\frac{Z_{C}}{Z_{A}} & \frac{Z_{C}}{Z_{B}} \\
\frac{Z_{A}+Z_{C}}{Z_{A}} & \frac{Z_{A}+Z_{C}}{Z_{B}}
\end{array}\right]\left[\begin{array}{c}
T_{A} \\
T_{B}
\end{array}\right]
$$

と表すことができる.ただし，各トルクの正方向は Fig. 4 の回 転方向と同一である。

オフセット駆動輪を用いた全方向移動機構においては，一般

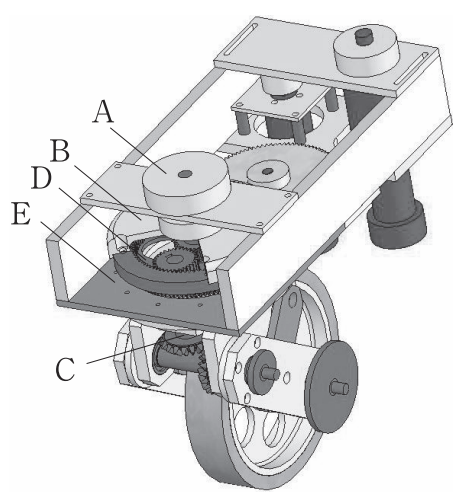

Fig. 5 Mechanism of DDSS Type P

Fig. 4 DDSS Type P 
に動作方向を変えるときに操舵軸を動作させる必要があるが, 定常動作（並進動作, 曲率一定の回転動作）においては操舵速 度 $\omega_{s}\left(=\omega_{D}\right)=0$ となる. 使用頻度がかなり高いと想定される この定常動作では $\omega_{D}=0\left(=T_{D}\right)$ となるため,

$$
\begin{aligned}
& T_{A}=-\frac{Z_{A}}{Z_{B}} T_{B} \\
& T_{C}=-\frac{2 Z_{C}}{Z_{A}} T_{A} \\
& T_{D}=0
\end{aligned}
$$

となり, 各回転速度は

$$
\begin{aligned}
& \omega_{A}=-\frac{Z_{C}}{Z_{A}} \omega_{C} \\
& \omega_{B}=\frac{Z_{C}}{Z_{B}} \omega_{C} \\
& \omega_{D}=0
\end{aligned}
$$

となるため, 出力 $P_{A}, P_{B}$ の比は

$$
\begin{aligned}
P_{A}: P_{B} & =T_{A} \omega_{A}: T_{B} \omega_{B} \\
& =\left(-\frac{Z_{A}}{Z_{B}} T_{B}\right)\left(-\frac{Z_{C}}{Z_{A}} \omega_{C}\right): T_{B} \frac{Z_{C}}{Z_{B}} \omega_{C} \\
& =1: 1
\end{aligned}
$$

となる。なお，操舵のみの出力 $\left(T_{C}=0\right)$ の場合は, 式 $(15)$, (20)より

$$
P_{A}: P_{B}=Z_{A}: Z_{B}
$$

となる. サンギアの径 $Z_{A}$ とプラネタリギアの径 $Z_{C}$ を同じにし た場合, サンギアとリングギア $Z_{B}$ の径の比は $Z_{A}: Z_{B}=1: 3$ となるため, $P_{A}: P_{B}=1: 3$ となる.

\section{4 提案二方式の相違点およびモータ運用率}

本論文では 2 種類の DDSS を提案しているが，それぞれ以下 の特徵を有している. 遊星歯車型 (Type $\mathrm{P}$ ) は構造上 $Z_{A} \neq Z_{B}$ となるため, 式 $(28)$ より操舵時には $P_{A} \neq P_{B}$ となり, 二つ のモー夕出力を等しくすることができない. モータ出力を等し くするためには, 傘歯車型（Type D）を用いる必要がある。一 方, 遊星歯車型は傘歯車型に比較して機構の全高が低い, 出力 軸の交差がないなど, 構造面で優れている。車両の仕様, 制作 上の条件に応じ，より適した型を採用すべきである。

次に，このモー夕運用率に基づいた提案機構と従来機構（駆 動と操舵を別のモータで行う方式）の比較を示す．な掞，本論 文ではモー夕運用率 $\delta$ を

$$
\delta=\frac{(\text { 各モータの動作時の平均出力の総和 })}{(\text { 各モータの定格出力の総和 })}
$$

と定義する。また，それぞれの機構で搭載する二つのモー夕の 定格出力比 $\left(P_{A 0}: P_{B 0}\right)$ については, 傘歯車型 (Type D), 遊 星歯車型（Type P）ともに $1: 1$ とし, 従来方式についても文 献 [10] の值 1:1 (駆動モー夕：操舵モー夕) を用いる.

$\delta$ の值を基本動作である直進（横，斜め方向への並進を含む）, 回転中心が一定の回転動作について考える（これらの動作では, 駆動出力のみで操舵出力がない). 必要となる全モー夕出力を $P$
とすると，それを実現するのに必要となるモー夕出力は金歯車 型 $\left(\right.$ Type D), 遊星歯車型 (Type P) ともに $P_{A 0}=P_{B 0}=\frac{P}{2}$ となり, $\delta=\frac{P}{P_{A 0}+P_{B 0}}=1$ となる. これに対して, 従来方式 では $P_{A 0}=P_{B 0}=P$ となるため, $\delta=\frac{P}{P_{A 0}+P_{B 0}}=0.5$ と なる. 一方, 操舵出力のみで駆動出力がない場合は, 傘歯車型 で $P_{A 0}=P_{B 0}=\frac{P}{2}, \delta=1$, 従来方式で $P_{A 0}=P_{B 0}=P$, $\delta=0.5$ となる. 遊星歯車型では式 $(28)$ より出力 $P$ の $3 / 4$ を $P_{B 0}$ で負担することになり, $P_{A 0}$ は $P_{B 0}$ と等しいので, $P_{A 0}=P_{B 0}=\frac{3 P}{4}, \delta=0.67$ となる. 操舵出力のみの場合に遊 星歯車型の運用率がやや低くなるが，何れにしても従来方式よ り高い値となっている. なお， $P_{A 0}$ に対する $P_{B 0}$ の比率を大き くすれば操舵出力のみの $\delta$ は大きくなるので $(1: 3$ で $\delta=1$. ただし，駆動出力のみの $\delta=0.67$ となる)，その中間的な比率 をとって全体の運用率を上げることも可能である，ただし，実 際の動作において操舵出力が大きくなるのは, 動きだしのキャ ス夕姿勢を調整するときのみである.

モー夕運用率が高いことより, 提案方式は従来方式に比べて モー夕を有効に使用している，すなわち同じ動作を実現するの に小出力のモータでよく, 小型化が可能になると考えられる.

\section{3. 全方向移動ロボットの構成}

提案した 2 種類の DDSS のうち，車高を抑えることができ， 移動ロボットベースとして構成が容易な遊星歯車型（Type P） の試作機を製作し，機構の動作確認を行った？その外観を Fig. 6 に，基本仕様を Table 1 に示す.

二つのモータの回転はベルトによりサンギア $A$ とリングギア $B$ に伝達され, 遊星歯車機構により駆動掞よび操舵トルクを生 成している.

この車輪を四つ使用して設計した全方向移動車の外観を Fig. 7 に，その主な仕様を Table 2 に示す. $100[\mathrm{~kg}]$ の荷重を搭載し

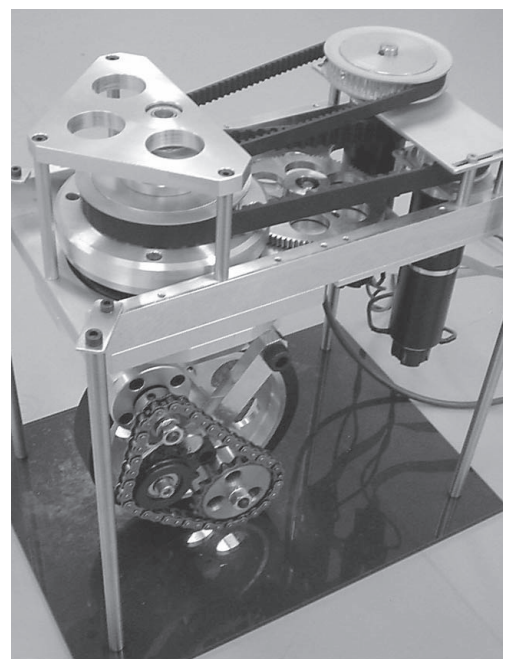

Fig. 6 Prototype DDSS Type P

Table 1 Specification of DDSS Type P

\begin{tabular}{|c|c|}
\hline Size $(\mathrm{D} \times \mathrm{W} \times \mathrm{H})$ & $300 \times 150 \times 300[\mathrm{~mm}]$ \\
\hline Weight & $11[\mathrm{~kg}]$ \\
\hline Motor power & $150[\mathrm{~W}] \times 2$ \\
\hline
\end{tabular}




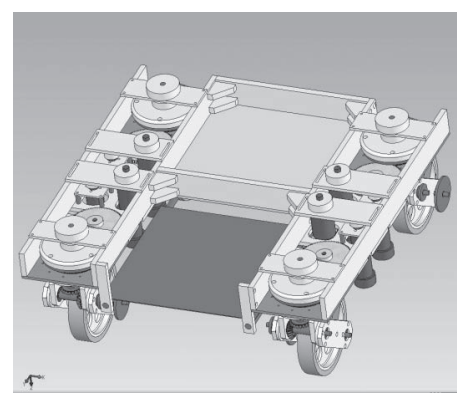

Fig. 7 Omnidirectional vehicle

Table 2 Specification of omnidirectional vehicle

\begin{tabular}{|c|c|}
\hline Size $(\mathrm{D} \times \mathrm{W})$ & $600 \times 600[\mathrm{~mm}]$ \\
\hline Weight & $70[\mathrm{~kg}]$ \\
\hline Motor power & $150[\mathrm{~W}] \times 8$ \\
\hline Max. velocity & $6[\mathrm{~km} / \mathrm{h}]$ \\
\hline Max. acceleration & $0.5\left[\mathrm{~m} / \mathrm{s}^{2}\right]$ \\
\hline Max. slope angle & $10[\mathrm{deg}]$ \\
\hline Max. step difference & $60[\mathrm{~mm}]$ \\
\hline Max. loading weight & $100[\mathrm{~kg}]$ \\
\hline
\end{tabular}

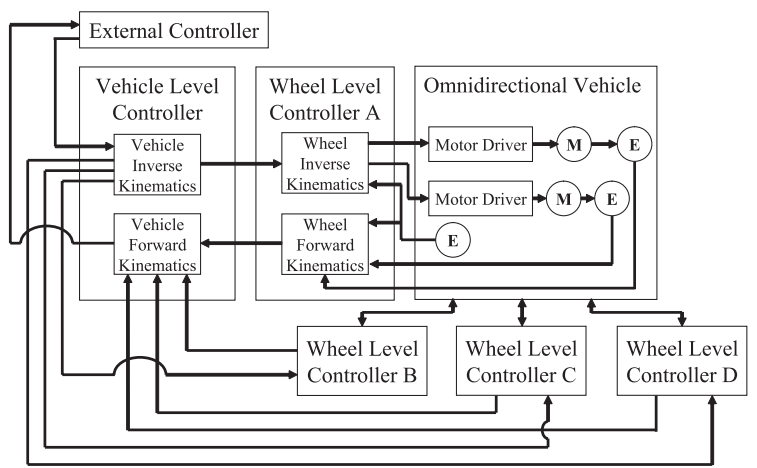

Fig. 8 Control system of omnidirectional vehicle

た状態で, $10^{\circ}$ の登坂能力, 最大加速度 $0.5\left[\mathrm{~m} / \mathrm{s}^{2}\right]$ と $60[\mathrm{~mm}]$ の段差乗り越え能力を実現できる出力のモー夕を選定している.

Fig. 8 にはその制御系の構成を示す. External Controller に おいて車両の軌道生成を行い, Vehicle Level Controller にお いて車両の軌道から各車輪位置での二次元速度を求めた後, 各 車輪の Wheel Level Controller によって式 (3) および式 (18) から二つのモー夕の指令速度に変換する.

\section{4. シミュレーション}

\section{1 シミュレーション方法}

機構設計／デザイン用 CAD ソフトウェア SolidWorks [13] を用いて各構成部品のモデル化および質量特性解析を行い, 機 構解析ソフトウェア DADS [14] にてユニットモデルを構築した 後, シミュレーションにて DDSS Type P の有効性を検証した.

SolidWorks の質量特性算出機能を使用して, 各軸回転体の 質量, 重心, 慣性モーメントを求めた。また，モータ，ギアボッ クスなど, DADS モデルに含まれない慣性は等価慣性モーメン トを求め, モデルに補正值を与えた. Table 3 に, 駆動時（旋 回台を固定した場合）と，操舵時（車輪を固定した場合）のそ
Table 3 Inertia moment

\begin{tabular}{|c|c|c|}
\hline & Sun Motor & Ring Motor \\
\hline Drive & $2.59 \times 10^{-2}\left[\mathrm{~kg} \mathrm{~m}^{2}\right]$ & $2.59 \times 10^{-2}\left[\mathrm{~kg} \mathrm{~m}^{2}\right]$ \\
\hline Steer & $5.43 \times 10^{-2}\left[\mathrm{~kg} \mathrm{~m}^{2}\right]$ & $6.03 \times 10^{-3}\left[\mathrm{~kg} \mathrm{~m}^{2}\right]$ \\
\hline
\end{tabular}

Table 4 Viscous friction coefficient

\begin{tabular}{|c|c|c|}
\hline & Sun Motor & Ring Motor \\
\hline Drive & $7.23^{-5}[\mathrm{Nmms} / \mathrm{rad}]$ & $7.23 \times 10^{-5}[\mathrm{Nmms} / \mathrm{rad}]$ \\
\hline Steer & $3.00 \times 10^{-3}[\mathrm{Nmms} / \mathrm{rad}]$ & $1.00 \times 10^{-3}[\mathrm{Nmms} / \mathrm{rad}]$ \\
\hline
\end{tabular}

Table 5 Gear ratio

\begin{tabular}{|c|c|c|}
\hline & Sun Motor & Ring Motor \\
\hline Motor-Steer Out & $\frac{52}{3}$ & 52 \\
\hline Motor-Drive Out & $\frac{104}{3}$ & $-\frac{104}{3}$ \\
\hline
\end{tabular}

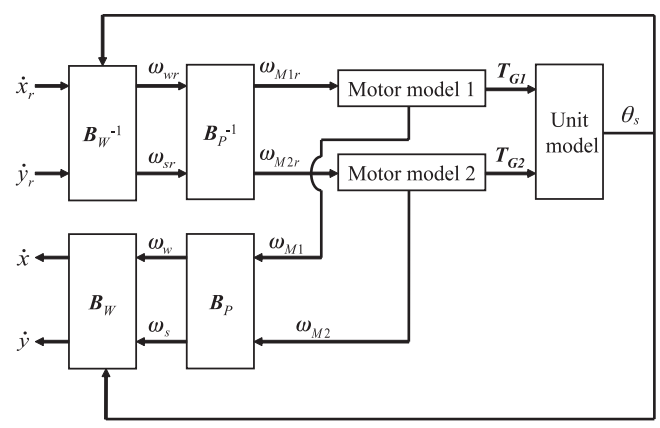

Fig. 9 Control system of DDSS

れぞれのモー夕出力軸における慣性モーメントを示す。本パラ メータはDADS のシミュレーション結果から求めた。

なお, 車輪半径 $r=80[\mathrm{~mm}]$, オフセット量 $s=50[\mathrm{~mm}]$ と し, 駆動, 操舵の転がり抵抗係数はそれぞれ, $2998.8[\mathrm{~N} \mathrm{~mm}]$, 624.8 [N mm] とした. また, 粘性摩擦抵抗はべアリングのみ考 慮した. Table 4 に, 駆動時と操舵時のそれぞれのモー夕出力 軸㧍ける等価粘性摩擦抵抗係数を示す. Table 5 に操舵のみの 場合と駆動のみの場合についての, サンモータ A, リングモー 夕 B から各出力軸までの減速比を示す.

Fig. 9 に一輪モデル (Fig. 8 における一輪分の Wheel Level Controller + Omnidirectional Vehicle) のブロック線図を示 す. 指令速度 $\dot{x}_{r}, \dot{y}_{r}$ を与えることにより, 各変換行列, モー タモデルを経て, DADS にて作成したユニットモデルに各モー 夕トルク $T_{G 1}, T_{G 2}$ が入力される. そして, モー夕回転数から 機構の速度 $\dot{x}, \dot{y}$ を求めている. $\theta_{s}$ は Fig. 1 で示した車輪の操 舵角度である。これに基づきシミュレーションを行った。

サンプリングタイムを $10[\mathrm{~ms}]$, 最高速度を $6[\mathrm{~km} / \mathrm{h}](\doteq$ $1.67[\mathrm{~m} / \mathrm{s}])$ とし, 最大加速度である $0.5\left[\mathrm{~m} / \mathrm{s}^{2}\right]$ にて加速し, 5 秒後に $-0.5\left[\mathrm{~m} / \mathrm{s}^{2}\right]$ で減速する台形速度入力を $+\mathrm{X}$ 軸方向, $-\mathrm{X}$ 軸方向, $+\mathrm{Y}$ 軸方向, $-\mathrm{Y}$ 軸方向に与えて, 一輪モデルの 挙動を検証した。なお，すべてのケースで初期姿勢は車輪の向 きが $+\mathrm{X}$ 軸方向 $\left(\theta_{s}=0\right)$ となるようにしている.

4.2 シミュレーション結果および考察

Fig. 10～13 にシミュレーション結果を示す. 順に $+\mathrm{X},-\mathrm{X}$, $+\mathrm{Y},-\mathrm{Y}$ 方向への並進移動（ $\theta_{s}$ の初期值はすべて 0$)$ の結果で ある。 $V_{x}$ は $\mathrm{X}$ 軸方向速度 $[\mathrm{m} / \mathrm{s}], V_{y}$ は $\mathrm{Y}$ 軸方向速度 $[\mathrm{m} / \mathrm{s}]$, 

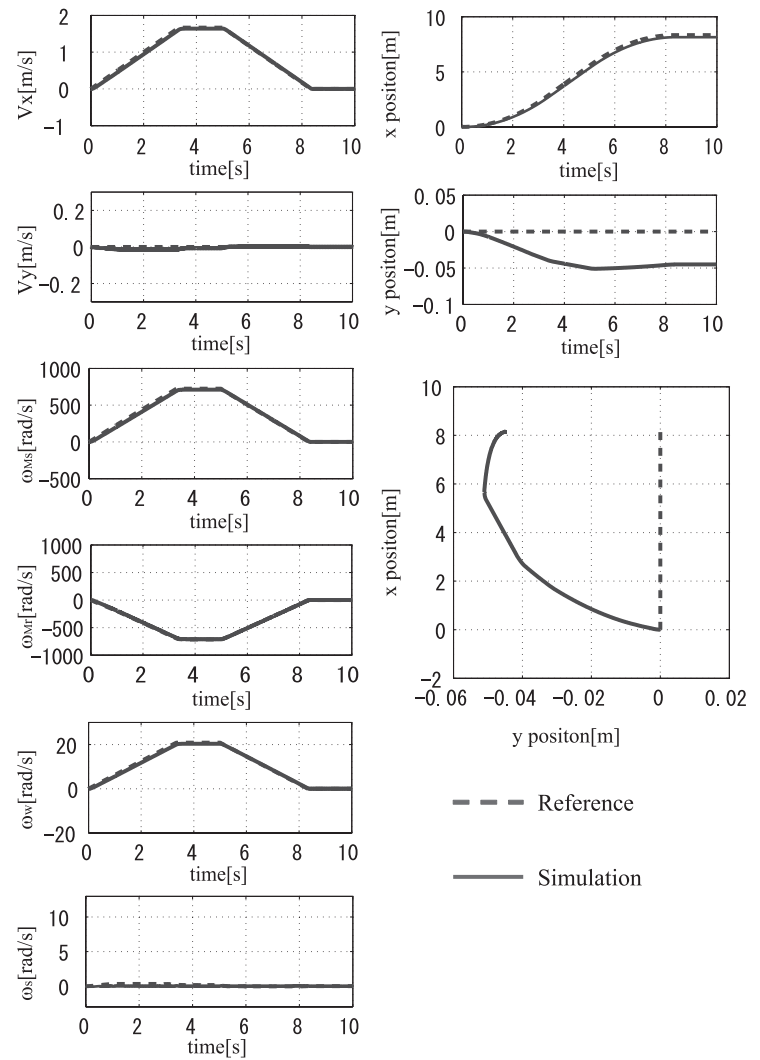

Fig. 10 Simulation results $\left(V_{x}=6[\mathrm{~km} / \mathrm{h}], V_{y}=0[\mathrm{~km} / \mathrm{h}]\right)$
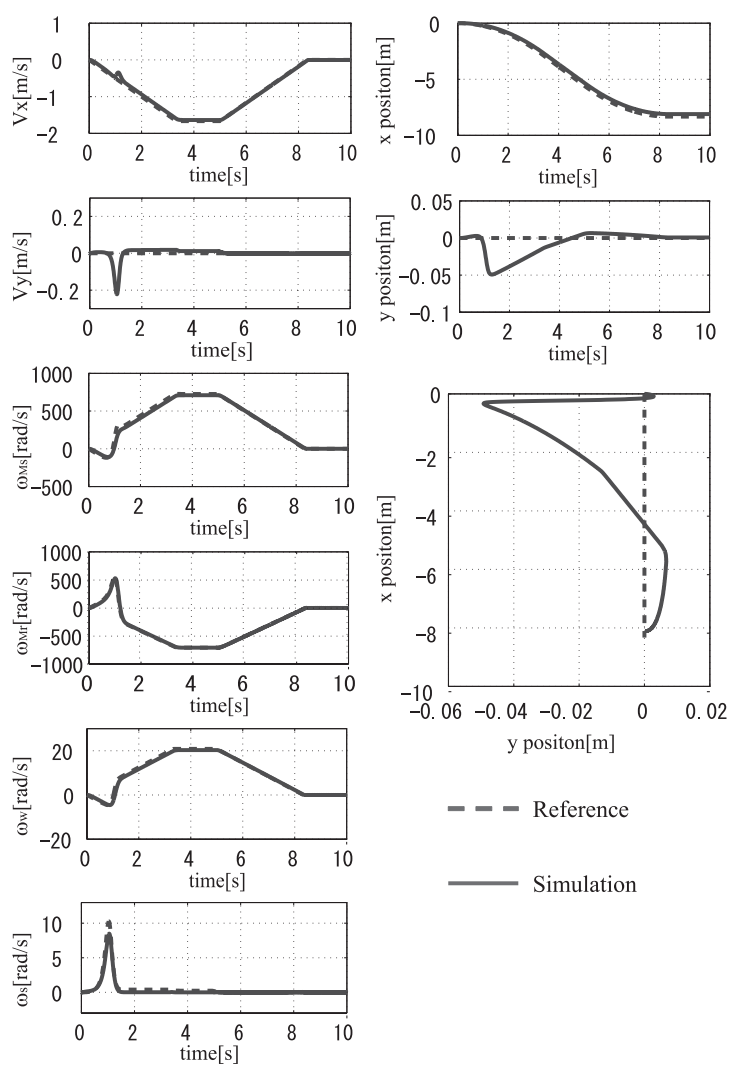

Fig. 11 Simulation results $\left(V_{x}=-6[\mathrm{~km} / \mathrm{h}], V_{y}=0[\mathrm{~km} / \mathrm{h}]\right)$

- - Reference

Simulation

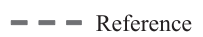

Simulation
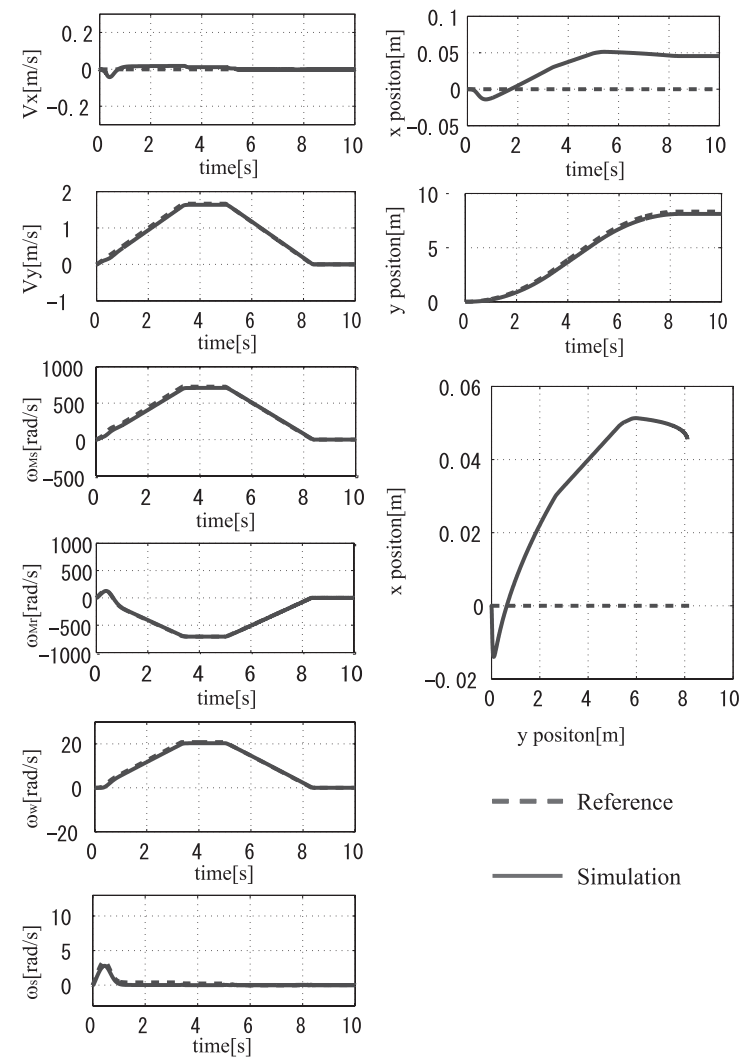

Fig. 12 Simulation results $\left(V_{x}=0[\mathrm{~km} / \mathrm{h}], V_{y}=6[\mathrm{~km} / \mathrm{h}]\right)$
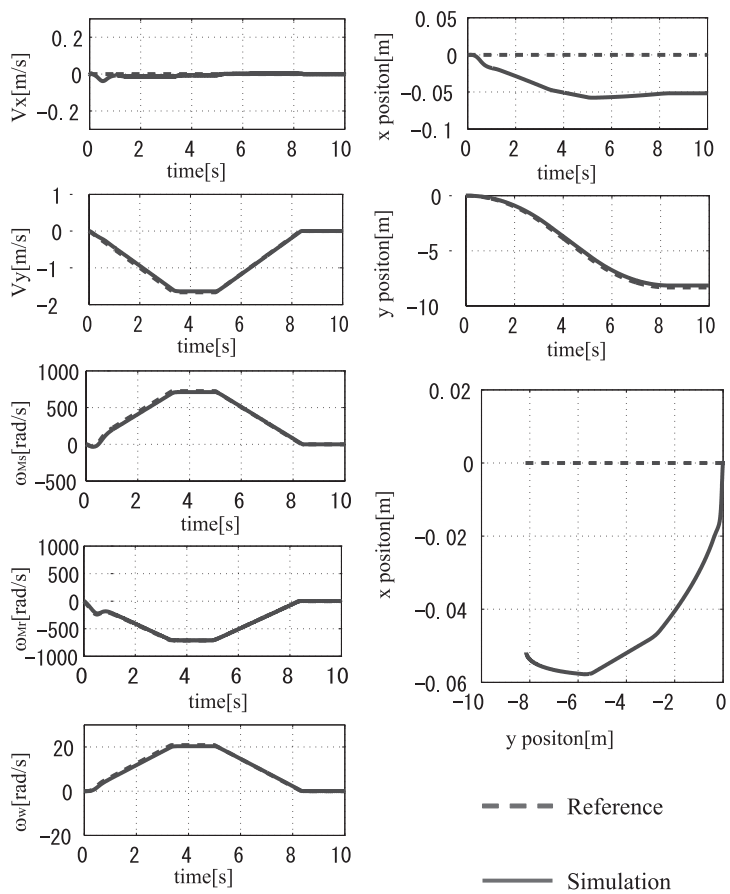

$\mathrm{y}$ positon[m]

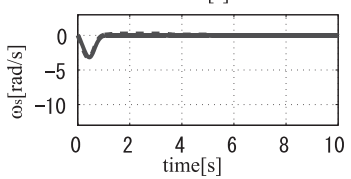

- - - Reference

Simulation

Fig. 13 Simulation results $\left(V_{x}=0[\mathrm{~km} / \mathrm{h}], V_{y}=-6[\mathrm{~km} / \mathrm{h}]\right)$ 
$\omega_{M s}$ はサン側モー夕角速度 $[\mathrm{rad} / \mathrm{s}], \omega_{M r}$ はリング側モー夕 角速度 $[\mathrm{rad} / \mathrm{s}], \omega_{w}$ は車輪角速度 $[\mathrm{rad} / \mathrm{s}], \omega_{s}$ は操舵角速度 $[\mathrm{rad} / \mathrm{s}]$ である。

シミュレーション結果より，すべてのケースでほぼ指令通り の動作が実現されていることが分かる. 走行距離約 $8[\mathrm{~m}]$ に対 して, 横方向の誤差は $6[\mathrm{~cm}]$ 以内に収まっている。 また, 例え ば Fig. 11 では車輪の初期姿勢と逆方向への運動になるので, 動 き始めのところで操舵角速度 $\omega_{s}$ が大きな值になっていること が確認できる，この $\omega_{s}$ の大きさは，指令速度によって決定す る. 今回のシミュレーションでは単純な台形速度指令としたた め, 動作開始時の $\omega_{s}$ がかなり大きな值になっているが, これ を小さくしたい場合は, 台形速度ではなく動作開始時の加速度 が小さくなるような速度指令值を用いればよい.

ただし，慣性，摩擦の影響から，車輪角速度，操舵角速度の 遅れ, 位置の定常偏差が生じている. 本機構では, 駆動と操舵 で慣性，摩擦が異なるため，これに対応できるコントローラの 設計が重要である．ユニット変換行列で操舵角度 $\theta_{s}$ を用いて いるため, 操舵が行われると, その操舵を戻す入力が与えられ, 定常状態においては二つのモー夕の追従性の違いによる影響は 抑えられる。

\section{5. 結言}

ホロノミック全方向移動のためのオフセット型駆動輪におい て, モー夕運用率を高くすることが可能な差動駆動操舵機構を 2 種類提案した. 2 種類の DDSS のうち, 車高を抑えることがで き, 移動ロボットベースとして構成が容易な遊星歯車型（Type P）の試作機を製作して，その動作確認を行うとともに，シミュ レーションによってその有効性を検証した。ささらに，提案した 機構を用いた全方向移動ロボットの設計を行った。

今後の課題としては以下の点があげられる.

・全方向移動ロボットの製作および走行実験

・不整地走行時に各車輪に加わる大きな外乱を考慮した姿勢 安定化制御

・本機構の全方向移動車いすへの適用
謝 辞 本研究の一部は, 科学研究費補助金（基盤 (C) 19560271，北川秀夫)，ならびに，21 世紀 COE プロジェク ト「インテリジェントヒューマンセンシング」(寺嶋一彦, 三好 孝典）の支援の下に実施された。

\section{参 考 文 献}

[ 1] M. West and H. Asada: "Design of a holonomic omnidirectional vehicle," Proc. IEEE Int. Conf. Robot. Automat., pp.97-103, 1992.

[2 2 F.G. Pin and S.M. Killough: "A new family of omni-directional and holonomic wheeled platforms for mobile robots," IEEE Trans. Robot. Automat., vol.10, pp.480-489, 1994.

[ 3 ] R. Damoto and S. Hirose: "Development of Holonomic Omnidirectinal Vehicle "Vuton-II" with Omni-Discs," Journal of Robotics and Mechatronics, vol.14, no.2, pp.186-192, 2002.

[ 4 ] H. Asama, et al.: "Development of an Omni-Directional Mobile Robot with 3 DOF Decoupling Mechanism," Proc. IEEE Int. Conf. on Robotics and Automation, pp.1925-1930, 1995.

[5] 北川秀夫, 別府達哉, 大野義則, 三好孝典, 寺嶋一彦: “全方向移動車 椅子の乗り心地向上のための走行制御”, 日本ロボット学会誌, vol.22, no.7, pp.933-939, 2004

[ 6 ] 北川秀夫, 西坂晋, 三好孝典, 寺嶋一彦: “介助式全方向移動車椅子の ためのパワーアシストシステムの構築”, 日本ロボット学会誌, vol.23, no.3, pp.321-329, 2005.

[ 7 ] T. Arai, E. Nakano, H. Hashino and K. Yamaba: "The Control and Application of "Omni-Directional Vehicle (ODV)"," Proc. 8th IFAC World Congress, pp.1855-1860, 1981.

[8] 森善一, 中野栄二, 高橋隆行, 高山訓治: “新しい全方向移動台車 ODV9 の機構とその走行モードについて”, 日本機械学会論文集 $(\mathrm{C}$ 編), vol.64, no.619, pp.951-958, 1998.

[9] 和田正義, 高木昭, 森俊二： “双輪キャス夕型駆動機構を用いたホロ ノミック全方向移動ロボット”, 日本ロボット学会誌, vol.18, no.8, pp.1166-1172, 2000.

[10] 和田正義, 森俊二：“ホロノミック全方向移動ロボットの開発”, 日本 ロボット学会誌, vol.15, no.8, pp.1139-1146, 1997.

[11] 和田正義: “同期キャスタ駆動機構によるホロノミック全方向移動ロボッ トの設計と運動解析”, 日本ロボット学会誌, vol.19, no.6, pp.784$792,2001$.

[12] 和田正義: “アクティブキャスタを用いた全方向移動ロボットのモデル化 と制御”，日本ロボット学会誌，vol.25, no.7, pp.1100-1107, 2007.

[13] http://www.solidworks.co.jp/

[14] http://www.lmsjapan.com/dads.htm

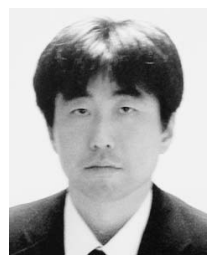

博士 (工学).

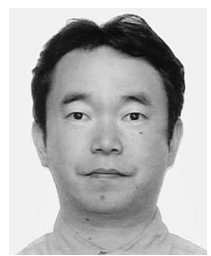

三好孝典（Takanori Miyoshi）

1989 年ローランド D.G (株) 入社. 1998 年豊橋技 術科学大学大学院修士課程生産システム工学専攻修 了 (社会人入学), 2001 年豊橋技術科学大学大学院 博士後期課程電子情報工学専攻修了, 2002 年ロー ランド D.G (株) 退社, 豊橋技術科学大学工学部生 産システム工学系講師. 2005 年助教授を経て現在 准教授. 計測自動制御学会, 日本機械学会, 計測自動制御学会, 日本鋳 造工学会, IEEE の会員. 博士 (工学)。(日本ロボット学会正会員)

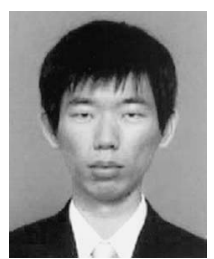

大野 貴 (Takashi Ohno)

2004 年豊橋技術科学大学エコロジー工学課程卒業. 2005 年同大学大学院生産システム工学専攻修士課 程に入学. 2007 年同大学同専攻修了. 2007 年アイ シン・エィ・ダブリュ株式会社に入社. 現在に至る.

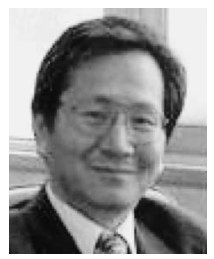

寺嶋一彦 (Kazuhiko Terashima)

1981 年京都大学大学院工学研究科博士後期課程修 了. 1982 年豊橋技術科学大学工学部生産システム 工学系助手. 講師, 助教授を経て 1994 年教授, 現 在に至る。1991 年 9 月〜1992 年 9 月ドイツミュ ンヘン工科大学客員研究員. システム制御理論とそ の応用，ロボティクスに関する研究に従事. システ 么制御情報学会, 日本機械学会, 日本鋳造工学会, IEEE 等の会員. 工学博士. 